settling suspension) and the analogy between momentum and mass transfer:

$$
\frac{\bar{k}_{L}}{k_{w}}=3.48\left\{\frac{V^{2}}{g D_{T}} \sqrt{\frac{g D_{p}}{\left(\rho_{p} / \rho_{w}-1\right) W^{2}}}\right\}^{-0.31}
$$

Figure 4 shows a comparison of Eq. (5) with the observed values shown in Fig. 1. The weighted average settling velocity $W$ in Eq. (5) was evaluated for a particle falling in a stagnant liquid. From the figure, the observed values deviate remarkably from Eq. (5) for the tube of small diameter and at high slurry velocities. Equation (5) is not always applicable to the experimental results obtained under flow conditions where no saltation was observed.

\section{Acknowledgment}

The authors would like to thank Mitsubishi Chemical Industries Ltd. and the Asahi Glass Foundation for Industrial Technology for their financial assistance. The assistance of student colleagues (Messrs. T. Yasumoto, T. Henmi, M. Isé, H. Funayama, K. Suzuki, H. Abé and H. Mabusé) is also appreciated.

$\begin{array}{llr}\text { Nomenclature } & \\ C_{D} & = & \text { drag coefficient of single particle moving } \\ & \text { at relative velocity } U_{r}\end{array}$

\begin{tabular}{|c|c|c|}
\hline$L_{T}$ & $=$ tube length & [m] \\
\hline$m_{d}$ & $\begin{array}{r}=\text { delivered concentration of particles } \\
\text { [volume }\end{array}$ & [raction] \\
\hline $\operatorname{Re}_{T}$ & $=$ Reynolds number $\left(=\left(U_{w}\right)_{\mathrm{av}} D_{T} / \nu\right)$ & {$[-]$} \\
\hline$S c$ & $=$ Schmidt number $(=\nu / \mathscr{D})$ & {$[-]$} \\
\hline$S h$ & $=$ Sherwood number $\left(=k_{L} D_{p} / \mathscr{D}\right)$ & {$[-$} \\
\hline$U_{r}$ & $\begin{array}{l}=\text { relative velocity between particles and } \\
\text { liquid }\end{array}$ & {$[\mathrm{m} / \mathrm{s}]$} \\
\hline$\left(U_{w}\right)_{\mathrm{ar}}$ & $\begin{aligned}= & \text { average liquid velocity across } \\
& \text { cross-section of tube }\end{aligned}$ & {$[\mathrm{m} / \mathrm{s}]$} \\
\hline$V$ & $=$ average velocity of suspension & {$[\mathrm{m} / \mathrm{s}]$} \\
\hline$W$ & $=$ weighted average settling velocity & {$[\mathrm{m} / \mathrm{s}]$} \\
\hline$\varepsilon$ & $\begin{aligned}= & \text { energy dissipation rate per unit mass of } \\
& \text { liquid defined by Eq. (1) }\end{aligned}$ & {$\left[\mathrm{m}^{2} / \mathrm{s}^{3}\right]$} \\
\hline$\varepsilon_{f 0}$ & $\begin{aligned}= & \text { energy dissipation rate per unit mass of } \\
& \text { liquid defined by Eq. (2) }\end{aligned}$ & {$\left[\mathrm{m}^{2} / \mathrm{s}^{3}\right]$} \\
\hline$\varepsilon_{s 0}$ & $\begin{aligned}= & \text { energy dissipation rate per unit mass of } \\
& \text { liquid defined by Eq. (3) }\end{aligned}$ & {$\left[\mathrm{m}^{2} / \mathrm{s}^{3}\right]$} \\
\hline$\nu$ & $=$ kinematic viscosity & {$\left[\mathrm{m}^{2} / \mathrm{s}\right]$} \\
\hline$\rho_{w}$ & $=$ liquid density & {$\left[\mathrm{kg} / \mathrm{m}^{3}\right]$} \\
\hline$\rho_{p}$ & $=$ particle density & {$\left[\mathrm{kg} / \mathrm{m}^{3}\right]$} \\
\hline
\end{tabular}

\section{Literature Cited}

1) Figueiredo, O. and M. E. Charles: Can. J. Chem. Eng., 45, 12 (1967).

2) Harriott, P.: AIChE J., 8, 101 (1962).

3) Ohashi, H., T. Sugawara, T. Yasumoto and T. Kijima: Reports of the Asahi Glass Foundation for Industrial Technology, 23, 91 (1973).

4) Ohashi, H., T. Sugawara, K. Kikuchi and T. Henmi: $J$. Chem. Eng. Japan, 12, 190 (1979).

5) Ohashi, H., T. Sugawara, K. Kikuchi and M. Isé: ibid., 13, 343 (1980).

6) Ohashi, H., T. Sugawara and K. Kikuchi: ibid., 14, 489 (1981).

(Presented in part at 2nd Pacific Chem. Eng. Congress, Denver, U.S.A., Aug., 1977.)

\title{
A METHOD FOR SOLVING DESIGN PROBLEM OF MULTICOMPONENT DISTILLATION
}

\author{
Ikuho YAMADA, Soo Gak LEE, Setsuro HIRAOKA, Shigehiko SUDA ANd MaSAo UCHIYAMA \\ Department of Industrial Chemistry, Nagoya Institute of Technology, Nagoya 466
}

A further rigorous method is proposed for determining the number of plates in enriching and stripping sections, $n$ and $s$, required for a specified doublet separation in multicomponent distillation by use of an ordinary column. This method employs the same approach proposed by Murdoch and Holland ${ }^{3)}$ (M-H method) to assign the degrees of freedom as the

\footnotetext{
Received September 19, 1981. Correspondence concerning this article should be addressed to I. Yamada.
}

design problem, and to determine $n$ and $s$ by a condition of minimum total number of plates, $n+s \rightarrow \min$. However, the proposed method is characterized by an accurate determination of an extremely small amount of molar rates of nondistributed components existing in the distillate (heavier than the heavy key) and bottoms (lighter than the light key) in the plate-to-plate calculation procedure ${ }^{5}$ within allowable significant figures of the computer, where the molar rates are 
determined by the condition of "plate-matching".

\section{Plate-to-Plate Calculation Procedure ${ }^{5)}$}

Denoting that the plates are numbered toward the feed plate for both sections of the column, the equations used in the plate-to-plate calculation procedure are as follows:

Enriching section

$$
\begin{gathered}
y_{j+1, i}=a x_{j, i}+b x_{D, i} \\
x_{j, i}=\frac{y_{j, i}-b x_{D, i}\left(1-E_{j, i}^{M V}\right)}{K_{j, i} E_{j, i}^{M V}+a\left(1-E_{j, i}^{M V}\right)} \\
\sum_{i} \frac{y_{j, i}-b x_{D, i}\left(1-E_{j, i}^{M V}\right)}{K_{j, i} E_{j, i}^{M V}+a\left(1-E_{j, i}^{M V}\right)}=1
\end{gathered}
$$

where $a \equiv R /(R+1), b \equiv 1 /(R+1)$, and $E_{j, i}^{M V}$ denotes the Murphree plate efficiency for the vapor phase. When an extremely small amount of $x_{D, i}$ for the nondistributed component is once assigned, $y_{1, i}$ is determined by the boundary condition at the condenser, and $x_{1, i}$ can be calculated from Eq. (2) with $K_{1, i}$ obtained by solving Eq. (3). Then $y_{2, i}$ is calculated by Eq. (1). These alternating calculations can be continued toward the feed plate as $j=2,3 \ldots f$.

Stripping section

$$
\begin{gathered}
x_{j+1, i}=a^{*} y_{j, j}+b^{*} x_{W, i} \\
y_{j, i}=y_{j-1, i}+E_{j, i}^{M V}\left(K_{j, i} x_{j, i}-y_{j-1, i}\right)
\end{gathered}
$$

where $a^{*} \equiv R^{*} /\left(R^{*}-1\right), b^{*} \equiv 1 /\left(R^{*}-1\right)$. The plateto-plate procedure in this section can be easily continued without any complicated procedure as mentioned for the enriching section, since the values of $x_{j, i}$ and $y_{j-1, i}$ which are required in the calculation of Eq. (5) have already been obtained by the previous step, where $y_{W, i}=K_{W, i} x_{W, i}$, in accordance with the boundary condition at the bottoms. That is, the bottoms is to be an ideal stage.

\section{Assignment of Molar Rates of Nondistributed Component}

The component $i$ is numbered in order of reciprocal relative volatility, and $h$ and $l$ denote the heavy and light key components, respectively. Usually, the molar rates of nondistributed components $D x_{, D i}$ $(i<h)$ and $W x_{W, i}(i>l)$, which cannot be specified previously as the design type of multicomponent distillation, are treated as zero $^{1,2)}$. However, if these are once set at zero, the values of $x_{j, i}$ for the nondistributed component, resulting from the plate-to-plate procedure are always zero throughout the column. This result obviously conflicts with the actual composition profile in the column. Therefore, one must consider a certain extremely small amount of unspecified $D x_{D, i}(i<h)$ and $W x_{W, i}(i>l)$ within a allowable significant figures of computer, and these rates must be determined by

\begin{tabular}{|c|c|c|c|c|c|c|c|}
\hline 1) & $\begin{array}{l}1 \\
2 \\
3\end{array}$ & $\begin{array}{l}1.0 \\
2.0 \\
3.0\end{array}$ & $\begin{array}{l}30.0 \\
40.0 \\
30.0\end{array}$ & $\begin{array}{r}\overline{1.0} \\
24.0\end{array}$ & $\begin{array}{r}30.0 \\
39.0 \\
6.0\end{array}$ & $\begin{array}{l}h \\
l\end{array}$ & \\
\hline 2) & $\begin{array}{l}1 \\
2 \\
3\end{array}$ & $\begin{array}{l}1.0 \\
2.0 \\
3.0\end{array}$ & $\begin{array}{r}20.0 \\
5.0 \\
75.0\end{array}$ & $\begin{array}{r}0.1 \\
4.9 \\
75.0\end{array}$ & $\begin{array}{c}19.9 \\
0.1 \\
-\end{array}$ & $\begin{array}{l}h \\
l\end{array}$ & $q=1.0$ \\
\hline 3) & $\begin{array}{l}1 \\
2 \\
3 \\
4\end{array}$ & $\begin{array}{l}1.0 \\
1.4 \\
2.4 \\
3.5\end{array}$ & $\begin{array}{l}20.0 \\
30.0 \\
30.0 \\
20.0\end{array}$ & $\begin{array}{r}- \\
\overline{0.2} \\
19.8\end{array}$ & $\begin{array}{r}20.0 \\
30.0 \\
29.8 \\
0.2\end{array}$ & $\begin{array}{l}h \\
l\end{array}$ & $\begin{array}{c}R=R_{m} \times \\
1.3\end{array}$ \\
\hline 4) & $\begin{array}{l}1 \\
2 \\
3 \\
4\end{array}$ & $\begin{array}{l}1.0 \\
1.4 \\
2.4 \\
3.5\end{array}$ & $\begin{array}{l}20.0 \\
30.0 \\
30.0 \\
20.0\end{array}$ & $\begin{array}{r}0.2 \\
29.8 \\
30.0 \\
20.0\end{array}$ & $\begin{array}{c}19.8 \\
0.2 \\
- \\
-\end{array}$ & $\begin{array}{l}h \\
l\end{array}$ & \\
\hline 5) & $\begin{array}{l}1 \\
2 \\
3 \\
4\end{array}$ & $\begin{array}{l}1.0 \\
1.4 \\
2.4 \\
3.5\end{array}$ & $\begin{array}{l}20.0 \\
30.0 \\
30.0 \\
20.0\end{array}$ & $\begin{array}{r}\overline{0.5} \\
29.5 \\
20.0\end{array}$ & $\begin{array}{r}20.0 \\
29.5 \\
0.5 \\
-\end{array}$ & $\begin{array}{l}h \\
l\end{array}$ & \\
\hline 6) & $\begin{array}{l}1 \\
2 \\
3 \\
4\end{array}$ & $\begin{array}{l}1.0 \\
1.4 \\
2.4 \\
3.5\end{array}$ & $\begin{array}{l}50.0 \\
10.0 \\
20.0 \\
20.0\end{array}$ & $\begin{array}{r}- \\
1.0 \\
19.0 \\
20.0\end{array}$ & $\begin{array}{r}50.0 \\
9.0 \\
1.0 \\
-\end{array}$ & $\begin{array}{l}h \\
l\end{array}$ & \\
\hline 7) & $\begin{array}{l}1 \\
2 \\
3 \\
4\end{array}$ & $\begin{array}{l}1.0 \\
1.4 \\
2.4 \\
3.5\end{array}$ & $\begin{array}{l}20.0 \\
10.0 \\
20.0 \\
50.0\end{array}$ & $\begin{array}{c}0.25 \\
9.75 \\
20.0 \\
50.0\end{array}$ & $\begin{array}{c}19.75 \\
0.25 \\
- \\
-\end{array}$ & $\begin{array}{l}h \\
l\end{array}$ & \\
\hline 8) & $\begin{array}{l}1 \\
2 \\
3 \\
4\end{array}$ & $\begin{array}{l}1.0 \\
1.4 \\
2.4 \\
3.5\end{array}$ & $\begin{array}{l}50.0 \\
25.0 \\
15.0 \\
10.0\end{array}$ & $\begin{array}{r}- \\
1.0 \\
14.0 \\
10.0\end{array}$ & $\begin{array}{r}50.0 \\
24.0 \\
1.0 \\
-\end{array}$ & $\begin{array}{l}h \\
l\end{array}$ & \\
\hline
\end{tabular}

Table 1 Specification for doublet separation of ternary and quaternary systems

(All runs are specified by $q=1.0, R=1.3 R_{m}$ )

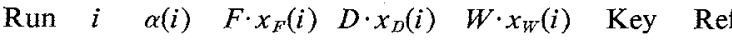

- denotes the nondistributed component. $R_{m}$ was determined by Underwood's method ${ }^{4)}$.

a condition of "plate-matching" written by the following equations.

$$
\begin{gathered}
g_{i} \equiv\left[y_{f, i}\right]_{D}-\left[y_{f, i}\right]_{W}=0 \quad(i \neq h, l) \\
g_{k}=\left[\frac{y_{f, l}}{y_{f, h}}\right]_{D}-\left[\frac{y_{f, l}}{y_{f, h}}\right]_{W}=0
\end{gathered}
$$

where []$_{D}$ and []$_{W}$ denote the values obtained by the plate-to-plate procedure for enriching and stripping sections, respectively.

\section{Calculation Steps for Determining $\boldsymbol{n}$ and $\boldsymbol{s}$}

By the definition of component numbering, doublet separation means $l=h+1$; that is, no split key exists between $h$ and $l$. Calculation steps are as follows:

1) Assume $n$

2) Assume $D x_{D, i}(i<h)$ and $W x_{W, i}(i>l)$

3) Calculate $\left(y_{f, i}\right)_{D}$ and $\left(y_{f, l} / y_{f, h}\right)_{D}$

4) Repeat the plate-to-plate procedure in the stripping section until Eq. (7) is satisfied, and determine $s$ and $\left(y_{f, i}\right)_{W}(i>l)$ simultaneously.

5) Judge Eq. (6). If this equation is satisfied within a given accuracy for all components, the calculation to determine $s, W x_{W, i}(i>l)$ and $D x_{D, i}(i<h)$ 


\begin{tabular}{|c|c|c|c|c|c|c|c|c|c|}
\hline \multirow{2}{*}{ Run } & \multirow{2}{*}{$\begin{array}{l}\text { Murphree } \\
\text { plate } \\
\text { efficiency }\end{array}$} & \multirow[b]{2}{*}{$n$} & \multicolumn{2}{|c|}{ L-M method } & \multirow[b]{2}{*}{$n /(n+s)$} & \multicolumn{4}{|c|}{ Proposed method } \\
\hline & & & $s$ & $n+s$ & & $n$ & $s$ & $n+s$ & $n /(n+s)$ \\
\hline 1 & $\begin{array}{l}1.0 \\
0.5\end{array}$ & $\begin{array}{l}14.4 \\
29.0\end{array}$ & $\begin{array}{l}10.2 \\
18.8\end{array}$ & $\begin{array}{l}24.6 \\
47.8\end{array}$ & $\begin{array}{l}0.585 \\
0.607\end{array}$ & $\begin{array}{l}15.7 \\
31.0\end{array}$ & $\begin{array}{r}9.0 \\
17.0\end{array}$ & $\begin{array}{l}24.7 \\
48.0\end{array}$ & $\begin{array}{l}0.636 \\
0.646\end{array}$ \\
\hline 2 & $\begin{array}{l}1.0 \\
0.5\end{array}$ & $\begin{array}{l}20.1 \\
41.4\end{array}$ & $\begin{array}{r}7.8 \\
12.4\end{array}$ & $\begin{array}{l}27.9 \\
53.8\end{array}$ & $\begin{array}{l}0.720 \\
0.770\end{array}$ & $\begin{array}{l}17.0 \\
38.0\end{array}$ & $\begin{array}{r}9.8 \\
17.9\end{array}$ & $\begin{array}{l}26.8 \\
55.9\end{array}$ & $\begin{array}{l}0.634 \\
0.680\end{array}$ \\
\hline 3 & $\begin{array}{l}1.0 \\
0.5\end{array}$ & $\begin{array}{l}20.0 \\
41.2\end{array}$ & $\begin{array}{l}27.5 \\
52.0\end{array}$ & $\begin{array}{l}47.5 \\
93.2\end{array}$ & $\begin{array}{l}0.421 \\
0.442\end{array}$ & $\begin{array}{l}22.3 \\
44.7\end{array}$ & $\begin{array}{l}25.4 \\
48.8\end{array}$ & $\begin{array}{l}47.7 \\
93.5\end{array}$ & $\begin{array}{l}0.468 \\
0.478\end{array}$ \\
\hline 4 & $\begin{array}{l}1.0 \\
0.5\end{array}$ & $\begin{array}{l}32.3 \\
65.9\end{array}$ & $\begin{array}{l}21.7 \\
40.6\end{array}$ & $\begin{array}{r}54.0 \\
106.5\end{array}$ & $\begin{array}{l}0.598 \\
0.619\end{array}$ & $\begin{array}{l}29.4 \\
63.0\end{array}$ & $\begin{array}{l}24.1 \\
43.0\end{array}$ & $\begin{array}{r}53.5 \\
106.0\end{array}$ & $\begin{array}{l}0.550 \\
0.594\end{array}$ \\
\hline 5 & $\begin{array}{l}1.0 \\
0.5\end{array}$ & $\begin{array}{l}14.4 \\
29.6\end{array}$ & $\begin{array}{l}14.0 \\
25.4\end{array}$ & $\begin{array}{l}28.4 \\
55.0\end{array}$ & $\begin{array}{l}0.507 \\
0.538\end{array}$ & $\begin{array}{l}15.0 \\
30.0\end{array}$ & $\begin{array}{l}15.0 \\
28.5\end{array}$ & $\begin{array}{l}30.0 \\
58.5\end{array}$ & $\begin{array}{l}0.500 \\
0.513\end{array}$ \\
\hline 6 & $\begin{array}{l}1.0 \\
0.5\end{array}$ & $\begin{array}{r}6.4 \\
13.4\end{array}$ & $\begin{array}{l}10.5 \\
18.6\end{array}$ & $\begin{array}{l}16.9 \\
32.0\end{array}$ & $\begin{array}{l}0.379 \\
0.419\end{array}$ & $\begin{array}{r}8.2 \\
15.6\end{array}$ & $\begin{array}{l}11.4 \\
21.6\end{array}$ & $\begin{array}{l}19.6 \\
37.2\end{array}$ & $\begin{array}{l}0.418 \\
0.419\end{array}$ \\
\hline 7 & $\begin{array}{l}1.0 \\
0.5\end{array}$ & - & - & - & - & $\begin{array}{l}26.0 \\
50.0\end{array}$ & $\begin{array}{l}19.9 \\
39.0\end{array}$ & $\begin{array}{l}47.9 \\
89.0\end{array}$ & $\begin{array}{l}0.543 \\
0.562\end{array}$ \\
\hline 8 & $\begin{array}{l}1.0 \\
0.5\end{array}$ & $\begin{array}{r}8.3 \\
17.2\end{array}$ & $\begin{array}{l}12.2 \\
22.0\end{array}$ & $\begin{array}{l}20.5 \\
39.2\end{array}$ & $\begin{array}{l}0.405 \\
0.439\end{array}$ & $\begin{array}{l}10.3 \\
19.9\end{array}$ & $\begin{array}{l}12.1 \\
22.7\end{array}$ & $\begin{array}{l}22.4 \\
42.6\end{array}$ & $\begin{array}{l}0.460 \\
0.467\end{array}$ \\
\hline
\end{tabular}

has just converged; then go to the next step. Otherwise return to 4) after correcting $D x_{D, i}(i<h)$ and $W x_{W, i}(i>l)$ where the Regula-Falsis method or the conjugated gradient method is useful in finding the corrected values.

6) Repeat 1)-5) for various $n$

7) Determine $n$ and $s$ by $n+s \rightarrow$ min.

The calculation steps mentioned in 1)-6) are based on $n$ assumed. When $s$ is assumed the relationship between enriching and stripping sections is reversed. The selection of assumption of $n$ or $s$ depends on the number of nondistributed components in distillate and bottoms. If the number of nondistributed components in distillate is less than that in bottoms, $n$ is assumed, otherwise $s$ is assumed. Furthermore, when the ideal plate is assumed, that is, $E_{j, i}^{M V}=1$, the equations describing the plate-matching are given as follows:

$$
\begin{gathered}
g_{i} \equiv\left[x_{f, i}\right]_{D}-\left[x_{f, i}\right]_{W}=0 \quad(i \neq h, l) \\
g_{k} \equiv\left[\frac{x_{f, l}}{x_{f, h}}\right]_{D}-\left[\frac{x_{f, l}}{x_{f, h}}\right]_{W}=0
\end{gathered}
$$

\section{Discussion and Conclusion}

Some numerical examples are illustrated to demonstrate the superiority of the proposed method over the method of Lewis and Matheson ${ }^{2)}$ (L-M method), in which the number of plates in each section is determined by the following relationships.

$$
\begin{aligned}
& {\left[\frac{x_{f, l}}{x_{f, h}}\right]_{D}=\frac{x_{F L, l}}{x_{F L, h}} \text { for } n} \\
& {\left[\frac{x_{f, l}}{x_{f, h}}\right]_{W}=\frac{x_{F L, l}}{x_{F L, h}} \text { for } s}
\end{aligned}
$$

For the doublet separation of ternary and quaternary systems as specified in Table $\mathbf{1}$, the values of $n, s$ and $n+s$ calculated are listed in Table 2. As observed in Table 2, one will fail to obtain the converged solution by the L-M method for a specification of $D \ll F$ or $W \ll F$ (See Run 7), whereas the proposed method always gives the stable solution for any complicated specification.

\section{Nomenclature}

$$
\begin{aligned}
& D \quad=\text { molar rate of distillate } \quad[\mathrm{mol} / \mathrm{hr}] \\
& E_{j, i}^{M V}=\text { Murphree plate efficiency of component } i \\
& \text { at plate } j \quad[-] \\
& F \quad=\text { molar rate of feed } \quad[\mathrm{mol} / \mathrm{hr}] \\
& K_{j, i}=K \text {-value for component } i \text { at temperature } \\
& \text { of plate } j \\
& n \quad=\text { number of plates in enriching section } \quad[-] \\
& R \quad=\text { reflux ratio } \quad[-] \\
& s \quad=\text { number of plates in stripping section } \quad[-] \\
& W \quad=\text { molar rate of bottoms }[\mathrm{mol} / \mathrm{hr}] \\
& x_{j, i}=\text { mole fraction of component } i \text { in liquid } \\
& \text { leaving plate } j \\
& y_{j, i}=\text { mole fraction of component } i \text { in vapor } \\
& \text { leaving plate } j \quad[-] \\
& y_{j, i}^{*} \quad=\text { mole fraction of component } i \text { in vapor phase } \\
& \text { in equilibrium with liquid phase leaving } \\
& \text { plate } j
\end{aligned}
$$

〈Subscripts〉

$\begin{array}{ll}D & =\text { distillate } \\ F & =\text { feed } \\ F L & =\text { liquid portion of feed } \\ f & =\text { feed plate } \\ h & =\text { heavy key component } \\ i & =\text { component number } \\ j & =\text { plate number } \\ l & =\text { light key component } \\ W & =\text { bottom product }\end{array}$




\section{Literature Cited}

1) Hirata, M.: “Taseibunkei no Jyoryu”, p. 94, Kagaku Gijyutsu Sha (1976).

2) Lewis, W. K. and G. L. Matheson: Ind. Eng. Chem., 24, 494 (1932).
3) Murdoch, P. G. and C. H. Holland: Chem. Eng. Progr., 48, 254 (1952).

4) Underwood, A. J. V.: Ind. Eng. Chem., 41, 2844 (1949).

5) Yamada, I., S. Suda and S. Hiraoka: J. Chem. Eng. Japan, 13, 498 (1980).

\section{APPLICATION OF VACANCY SOLUTION THEORY TO ADSORPTION FROM DILUTE AQUEOUS SOLUTIONS}

KENJI FUKUCHI

Department of Industrial Chemistry, Ube Technical College, Ube 755

SHIGETOSHI KOBUCHI AND YASUHIKo ARAI

Department of Chemical Engineering, Kyushu University, Fukuoka 812

In the design of purification facilities for removing organic pollutants from wastewaters by using activated carbon, equilibrium adsorption information is required. Since wastewaters contain more than one component, the desired equilibria are for multiple solutes rather than for a single solute. However, most of the published papers in this field deal with adsorption for removing a single solute from water. In the present study, the vacancy solution theory which has been proposed to predict gas mixture adsorption equilibria is applied to the adsorption equilibria of aqueous solutions in order to develop a new correlation method.

The vacancy solution theory, proposed by Suwanayuen and Danner ${ }^{3,4}$, is found to be very useful for correlating single gas adsorption isotherms and gas mixture adsorption equilibria. By replacing the vacuum space with water molecule as a definition of "vacancy" in the theory, one can readily derive an adsorption isotherm equation for dilute aqueous solutions. In the derivation, the Gibbs adsorption equation for dilute solutions, $R T d \ln c_{i}^{\circ}=\left(A / n_{i}^{\circ}\right) d \pi$, was used and the Wilson equation was adopted to describe the nonideality in the adsorbed phase. The adsorption isotherm equation obtained for a dilute aqueous solution containing a single solute $i$ is as follows.

$$
\begin{aligned}
c_{i}^{\circ}= & {\left[\frac{n_{i}^{\circ}, \infty}{H_{i}}-\frac{\theta_{i}}{1-\bar{\theta}_{i}}\right]\left[\Lambda_{i 3} \frac{1-\left(1-\Lambda_{3 i}\right) \theta_{i}}{\Lambda_{i 3}+\left(1-\Lambda_{i 3}\right) \theta_{i}}\right] } \\
& \times \exp \left[-\frac{A_{3 i}\left(1-\Lambda_{3 i}\right) \theta_{i}}{1-\left(1-\Lambda_{3 i}\right) \theta_{i}}-\frac{\left(1-\Lambda_{i 3}\right) \theta_{i}}{\Lambda_{i 3}+\left(1-\Lambda_{i 3}\right) \theta_{i}}\right]
\end{aligned}
$$

where Henry's Law constant, $H_{i}$, is defined by

$$
H_{i}=\lim _{c_{i}^{\circ} \rightarrow 0}\left(\frac{n_{i}^{\circ}}{c_{i}^{\circ}}\right)
$$

Received October 23,1981. Correspondence concerning this article should be addressed to $Y$. Arai. and

$$
\theta_{i}=\frac{n_{i}^{\circ}}{n_{i}^{\circ, \infty}}
$$

Four independent parameters, $n_{i}^{\circ, \infty}, H_{i}, A_{i 3}$, and $\Lambda_{3 i}$, in Eq. (1) should be determined empirically by fitting the experimental data. A least-squares fitting procedure was used to obtain these isotherm parameters from the single-solute adsorption data reported by Radke and Prausnitz ${ }^{1}$. The values of the four parameters are listed in Table 1 . The results are sensitive to selection of $n_{i}^{\circ}, \infty$ and $A_{3 i}$ among these parameters. If the adsorbed phase is assumed to be ideal (i.e., $A_{i 3}=A_{3 i}=1$ ), Eq. (1) is the same as the Langmuir adsorption isotherm. Every set of Wilson's parameters shown in Table 1 shows a negative deviation from the ideal-solution law (i.e., $\gamma_{i}, \gamma_{3}<1$ ). The deviation becomes large, with increasing values of $A_{i 3}$ and $A_{3 i}$.

The vacancy solution theory can be extended to multicomponent systems. The adsorption equilibrium equation for a dilute aqueous multi-solute system is represented by

$$
c_{i}=\gamma_{i} z_{i} n_{T} \frac{n_{i}^{\circ, \infty} A_{i 3}}{n_{T}^{\infty} H_{i}} \exp \left(\Lambda_{3 i}-1\right) \exp \left(\frac{\pi \tilde{a}_{i}}{R T}\right)
$$

where

$$
\frac{\pi \bar{a}_{i}}{R T}=-\left[1+\frac{n_{T}^{\infty}-n_{i}^{\circ, \infty}}{n_{T}}\right] \ln \gamma_{3} x_{3}
$$

and

$$
\ln \gamma_{i}=1-\ln \left(\sum_{j} x_{j} A_{i j}\right)-\sum_{k}\left(\frac{x_{k} A_{k i}}{\sum_{j} x_{j} A_{k j}}\right)
$$

with

$$
n_{T}^{\infty}=\sum_{i} z_{i} n_{i}^{\circ, \infty} \quad \text { and } \quad n_{T}=\sum_{i} n_{i} \quad(i=1,2)
$$

